\title{
Some Language Features in Italian Opera Librettos of XVII-XVIII Centuries
}

\author{
Luca Pavan \\ Institute of Foreign Languages, Faculty of Philology, Vilnius University, Vilnius, Lithuania
}

Email address:

pavan@panservice.it

\section{To cite this article:}

Luca Pavan. Some Language Features in Italian Opera Librettos of XVII-XVIII Centuries. International Journal of Literature and Arts. Vol. 7, No. 6, 2019, pp. 172-178. doi: 10.11648/j.ijla.20190706.17

Received: November 9, 2019; Accepted: December 6, 2019; Published: December 11, 2019

\begin{abstract}
The article examines the language used in some Italian opera librettos in XVII- XVIII centuries. The analysis was carried out with the support of two software tools: an automatic translator from Florentine vernacular language to modern Italian language, created by the author, and a software tool, available on internet, helping to find common phrases while comparing two texts. It is well known that from the outset of opera, the librettists mainly used the Florentine vernacular language, considered by poets and scholars as a model of beauty and balance. At the same time the language used in opera librettos follow some other basic rules described in more details in this article. The poetical structures and, sometimes, the choice of the language itself demonstrates that poetry used in librettos was also influenced by the music. Opera's role in the society distinguished librettos from works of literature. Operas became very popular among several social classes and at the same time became an economical resource for many theaters in the Italian peninsula, while the literature had eventually less economic impact. This sometimes could have changed the language of librettos, adapting it to the needs of emergent social classes like the merchants, the economic status of whom significantly improved from XIV century. The author shows that, even if several features of librettos were changing along centuries, their language was almost always related with the language of literature. Even if writing a libretto sometimes was dictated by compromises with the market of operas and the requests of audience, nevertheless, librettos can be considered as a part of the Italian literature.
\end{abstract}

Keywords: Automatic Translation, Florentine Vernacular Language, Italian Literature, Opera Librettos

\section{Introduction}

The first opera librettos were written for the Italian courts of Florence and Mantua between the end of XVI century and the beginning of XVII century. They were the result of several criteria set up by a small group of intellectuals and aristocrats. A libretto had to be closely connected with music to create a new kind of theater consisting of words and singing. To achieve this, the libretto had to follow some basic rules. At the very beginning of opera their librettos had to be written using the Florentine vernacular. However, in some exceptional cases the singers could perform arias in different languages or in dialect, for example in some opera like $\mathrm{Li}$ zite ' $n$ galera (1722), written using the Neapolitan dialect [1]. In such cases the librettos were probably written for a certain kind of audience and for commercial reasons. In fact, the popularity of opera increased significantly in many Italian towns within a few years creating a huge business.
Even if many librettos are written in vernacular language, some questions arise about the influence of literature: how much the literature influenced the text of librettos? Can librettos be regarded as part of literature? The analysis of several librettos texts assists the author answering these questions.

In this article the author wants to demonstrate that not only the texts of librettos were heavily influenced by literature, but they also can be regarded as a part of literature themselves. Along several centuries the librettists used many words and phrases as in the poetry of classic authors, starting from Dante and Petrarca. In addition, the music makes a libretto something different from the usual structures of poetry. In fact, the discussion on whether the music or text makes bigger influence on opera continued along the history. From the musicologists' point of view music is regarded to be more important than the librettos [2]. However, the most recent studies show that librettos are well-connected with literature 
and it is possible to assess their quality according to the language [3].

Some rules were followed while writing the librettos, at least at the beginning of opera. However, later these rules were not always respected.

\section{Method}

The number of opera librettos in this period is very high. So, for the purposes of this article the choice of librettos is done mainly according to popularity at their time.

The comparison of various Florentine vernacular poetry works with the opera librettos obviously is the best way to find out the impact of language features to librettos of the particular period. For such comparison purposes two software tools were used: an automatic translator from Florentine vernacular language to modern Italian language and a software tool helping to find identical phrases or parts of them while comparing two texts.

An automatic translator for Personal Computer was written in $\mathrm{C}$ language by the author and already described in a previous article [4]. This tool can be used to translate automatically some librettos of XVII and XVIII century from Florentine vernacular language into modern Italian language. The translator not only replaces words and phrases into modern Italian language, but it also provides a file with statistics with the list of replacements and their frequency in the text. Such statistics' file helps to check whether the lexicon of XIV century vernacular literature was used in librettos.

Another software tool used for this research was a program available on the internet to find identical phrases or parts of them in two texts. This assists to check which authors of poetry influenced the style of the librettos.

\section{The Early Opera Librettos}

The first opera libretto, Dafne, was written in Florence around 1595 by Ottavio Rinuccini. This libretto follows the rules elaborated by the so-called Camerata de'Bardi, a group of intellectuals which started to discuss about music and poetry already from 1576 . First of all, the language had to be based on the models of Florentine vernacular poetry. The prose could not be used in writing librettos, because it was not compatible with the rhythms of music. Secondly, it was necessary to follow the theories of Aristotle about the ancient Greek theater. The plot of early librettos derived from Greek and Roman myths and the action had to be maximum in one day, according to the Aristotle's rules [5].

With few exceptions, the poetry of the first librettos used mainly syllabic verses of seven and eleven syllables, but sometimes also of eight, four or five syllables [6]. This rule changed only after several decades, when the authors started to use more often also syllabic verses of three, five and eight syllables. This new trend was also influenced by Gabriello Chiabrera, who encouraged the authors of librettos to experiment with different syllabic verses [1].
The opera had to use a modern language, the Florentine vernacular coming from the vernacular literature. Already in Dafne, as in all early librettos, the influence of Petrarca is remarkable [7].

In 1607 La favola d'Orfeo by Alessandro Striggio (music composed by Claudio Monteverdi) was performed in Mantua. The dramatic aspect of the Orfeo's tale is the main accent of this Striggio's libretto. It could be observed that the language is still under the strong influence of Petrarca,

Striggio uses some expressions found in Petrarca's verses, like for example:

Io la Musica son, ch'a i dolci accenti

so far tranquillo ogni turbato core,

In Petrarca's Canzoniere (V, 4) we find:

LAUdando s'incomincia udir di fore

il suon de' primi dolci accenti suoi.

Or, for example, Striggio writes:

del nostro semideo, cantiam, pastori,

in sì soavi accenti

In Petrarca (Canz. CCLXXXIII, 6) we find:

In un momento ogni mio ben m'hai tolto.

post'hai silenzio a' piú soavi accenti

We can find the following reference to the metaphor of Euridice's loss in the libretto:

Qual poter, qual furor da questi orrori,

da questi amati orrori

mal mio grado mi tragge e mi conduce

a l'odiosa luce?

In Petrarca (Canz. VI, 9) we find a similar dramatic context, where "Amore" is a force which brings death:

Et poi che ' 1 fren per forza a sé raccoglie,

i' mi rimango in signoria di lui,

che mal mio grado a morte mi trasporta.

Though Petrarca obviously had the influence to Striggio's libretto language, the influence of Dante's Divine Comedy also can be found. For example, in the quotation of the famous verse "Lasciate ogni speranza o voi ch'entrate" [8].

Several metaphors in the libretto (the poet's eyes, called "le luci mie") also are found in Dante (Inf., XXIX, 2):

La molta gente e le diverse piaghe

avean le luci mie sì inebriate,

che de lo stare a piangere eran vaghe.

However, Petrarca (Canz. C, 14) uses the same metaphor to describe the eyes:

O de le luci mie luci serene;

S'un vostro sguardo può tornarmi in vita,

ahi, chi nega il conforto a le mie pene?

Similarly, in the libretto there is the metaphor of the light ("il dolce lume"):

Ma mentre io canto, ohimè chi m'assicura

Ch'ella mi segua? Ohimè, chi mi nasconde

de l'amate pupille il dolce lume?

In Petrarca this metaphor is very frequent (Canz. XI, LXXII, CVI, CXLII, CLXIII), but it is found also in Dante (Inf. $\mathrm{X}$ and XIII).

Many other similar examples similar to Petrarca in the libretto can be found, like "soavi parole" (Canz. CCLXXIII, 
5), "candido seno" (Canz. CLX, 11), "luci beate e liete" (Canz. LXXI, 57). In one case Striggio uses a complete verse of Petrarca: "come nulla qua giù diletta e dura" (Canz. CCCXI, 14).

As it was showed, Striggio uses a poetic style derived from Dante and even more from Petrarca. This probably contributed, along with music, to the great success of Orfeo. This opera also includes the first aria of history ("Vi ricorda, o boschi ombrosi") [8] and it became so popular that it is often performed even nowadays.

The early opera librettos also follow the rules described by Pietro Bembo in Prose della volgar lingua (1525). According to Bembo's rules Petrarca is the main authority for the style of poetry, so he is very much imitated in the librettos and, in general, in all vernacular poetry.

Even if Petrarca's influence to language of librettos became weaker from the half of XVII century, we still can find use of Petrarca expressions, for example, in a libretto from 1643, L'incoronazione di Poppea, by Gian Francesco Busenello. The music was written by Claudio Monteverdi and the plot is set in the ancient Roman time. This opera is a drama, but breaks with traditional mythological plots, setting up, for the first time, a historical plot [1]. The opera was performed in Venice and, at that time, Busenello belonged to the Accademia degli Incogniti, a group of intellectuals in Venice which wrote experimental works against the authority of famous literature authors [9]. It could be observed that the libretto is influenced by Petrarca. For example, in the libretto we find these verses, in which the "Virtù" is speaking:

Io son la vera scala,

per cui natura al sommo ben ascende.

We find in Petrarca's Canzoniere (XIII, 10) the same "Sommo ben" which is brought by Laura:

Da lei ti vèn l'amoroso pensero,

che mentre '1 segui al sommo ben t'invia,

"Sommo Ben" is an expression introduced by Dante in several places of Divine Comedy, like in Purg. XXVIII, to describe God.

In another part of the libretto Busenello describes Poppea like this:

Apri un balcon Poppea

col bel viso in cui son le sorti mie,

In Petrarca (Canz. CCLXXXIX, 10) there is the same expression about Laura:

Lei ne ringratio, e ' 1 suo alto consiglio,

che col bel viso et co' soavi sdegni

faceami ardendo pensar mia salute.

In the libretto we also find:

Le meraviglie, Amor,

son opre di tua man,

In Petrarca (CCVII, 64) there is some similar expression about "Amore":

Amor, et vo' ben dirti,

disconvensi a signor l'esser sí parco.

Tu hai li strali et l'arco:

fa' di tua man, non pur bramand'io mora,

ch'un bel morir tutta la vita honora.
In Busenello's libretto there are words like "cataratte", "urbanità" or "secretezza" which are not commonly used by the previous poets. These words are not coming from the literature, but from other fields of knowledge. Also, the serious features are mixed with comic features, leaving us the doubt how to judge Poppea [10]. This will become a common practice from the second half of the century. Meanwhile the Accademia degli Incogniti created librettos broking the traditional stylistic features of the previous authors. The plots of some operas mixes the mythological elements with comic style, creating characters at the same time heroic and comic, for example in L'Eneide travestita by Giovan Battista Lalli (1634) [11]. The librettos started to change the original features including previously avoided comic elements. The baroque librettos enlarged the possibilities of libretto's style, as we will see in the next chapter.

\section{The Second Half of the XVII Century}

Towards the half of the XVII century the connection between librettists and Petrarca's style is high, but the librettos started to enlarge their lexical possibilities with new words. This is easy to understand: the Italian peninsula had many dialects and the audience of operas started to include different social classes. The operas could be performed for kings and aristocrats therefore, they were very expensive. However, majority of operas were created for a larger audience and following the tendencies of the market, as it happened in Venice [9].

Operas started to experiment with different plots, not only derived from myths. The lexicon used by Petrarca was not anymore enough complex to describe the new stories in the plots, so the librettists were constrained to enlarge their dictionary. However, Petrarca was never forgotten and many elements of his style persists in most of the operas.

One of the most popular opera's composers of the XVII century was Francesco Cavalli, who together with the librettist Giacinto Andrea Cicognini, wrote the opera Giasone in 1644. This opera is probably the biggest success of the century, with many replicas in Venice and in many other Italian towns. Cicognini had an important role in the Accademia degli Incogniti and the libretto of Giasone shows many features which reflects the new trends in opera's plot: Giasone is not a hero, but a vicious man; Medea is a jealous woman with magic powers; Oreste is a slave and so on. There are also comic characters like the slave Demo. Everything in the plot is adapted to the new taste of the audience and the language of the libretto is also different from the standard of the beginning of the century. Petrarca's style is still possible to find in this libretto, like for example:

e così forte imprime

l'altrui passioni entro la propria idea

ch'or s'allegra or si duole, or ride or piange,

or s'umilia or s'adira,

conforme alla cagion per cui delira.

In Petrarca's Canzoniere (CXXIX, 8) we find these verses: 
ivi s'acqueta l'alma sbigottita;

et come Amor l'envita,

or ride, or piange, or teme, or s'assecura;

Other vernacular expressions of the libretto also come from Petrarca, for example, "il mio core" and "il mio bene", but there are as well parts of verses similar to Dante's Comedy, like "di quella fede" and "in questo loco".

There are some other authors who influenced librettists in the XVII century, especially in the creation of the plots. It is possible to find the influence of Ludovico Ariosto, who also sometimes mixed dramatic and comic elements together. Ariosto, in Orlando Furioso, created a poem made of different styles. The plot's complexity of Orlando Furioso was similar to the complexity of the Italian opera's plots of the XVII century. Some operas performed in Venice were based on Ariosto's poem and bilingual. Comic heroes of the poem could speak, for example, also in French. However, at the end of XVII century, the group of poets belonging to the Accademia dell'Arcadia wished to stop all these experiments coming back to the Aristotle's rules and the classic poetry, influencing the librettists [12]. Notably, thanks to the composer Georg Friedrich Händel, some of the best operas based on Ariosto's Furioso became popular in the first half of XVIII century outside of Italy and were performed mainly in London. Despite the success of Ariosto, in the majority of Italian operas Dante and especially Petrarca were never forgotten as the models of literature to imitate writing the librettos.

One of the major opera's composers of the XVII century was Antonio Cesti, who wrote the music for some important operas, like Orontea (1656, with the libretto by Cicognini) and Il pomo d'oro (1667, with the libretto by Francesco Sbarra). In Orontea Cicognini still uses a language influenced by Petrarca. Some expressions coming from Petrarca could be found: "i miei danni", "alta beltà", "a sdegno". Orontea was performed in Innsbruck and showed the success of the Italian operas also outside of Italy. Cesti worked for the Austrian emperor Leopold, who liked operas and supported musicians and librettists. So, after ten years, Cesti wrote for the emperor Il pomo d'oro, probably the most magnificent baroque opera of the century. Its duration was about eight hours, there were about fifty characters and many special machines were built for the performance [9]. Again, the language of the Sbarra's libretto shows some Petrarca's imitation, for example in this part:

io vidi al lacrimare

di questi afflitti lumi, i duri sassi

fin dagl'antri dolenti

forman l'eco talora ai miei lamenti,

replica spesso il suon de' miei sospiri,

In Petrarca's Canzoniere and in Dante's Comedy we often find the word "lume" to describe the light of the eyes, as already it was showed in the previous chapter. Anyway, also "i miei sospiri" appears in many Petrarca's verses (Canz. L, 60; CXVII, 5; CVIII, 2; CCXXXIX, 8; CCCV, 8; CCCXVIII, $10)$. Another part of the libretto recalls a constellation ("carro stellato"):
Giunone sopra il carro stellato d'Arturo, che cammina per la via Lattea formata di piccolissime stelle, Venere.

The same expression "carro stellato" is used by Petrarca (Canz. CLXIV, 3):

Notte il carro stellato in giro mena

et nel suo letto il mar senz'onda giace,

It should be noted that even if Petrarca's poetical expressions sometimes appear in the libretto, in comparison with the early opera librettos, there is a less influence of Tuscany's poets of XIV century. Il pomo d'oro was written for an official reason (the birth of the Austrian emperor's son), but the language started to use a more extensive dictionary. In 1612 the first edition of the Vocabolario degli Accademici della Crusca was printed [13] including words from many authors. These words enlarged the poets' dictionary, including new terms coming from different fields other than literature. The tendency was in fact to give the status of "language of literature" to the Florentine vernacular", extending the number of words and their possible use in different contexts of the society.

\section{Some Examples from the XVIII Century}

As it was stated in the previous chapter, the writers which founded the Accademia dell'Arcadia mainly wanted to react to the excesses and experiments of the baroque period. The aim was to come back to the classic poetry of Dante and Petrarca, and to have Homer as a model of the Greek literature. This new classic tendency was also followed by several librettists along the XVIII century. They started to avoid too much complicated plots, using a poetic style closer to the classic poets of literature and at the same time choosing words and poetical expressions coming from their period. Still existing the Accademia dell'Arcadia became the promoter of a poetry which was far from experimentation as well as from the use of a complicated language.

The major XVIII century's librettists belonging to the Accademia dell'Arcadia were Apostolo Zeno and Pietro Metastasio. They were the authors of many librettos according to the new tendency. One of the major Metastasio's successes is certainly the libretto for the opera Didone abbandonata, a serious opera performed in Naples in 1724. This libretto became so popular that, along the century, dozens of composers wrote the music for it. Metastasio's language in this libretto is less complicated in comparison to the one of the baroque period, but there is also a choice of poetical words and expressions which it is possible to find in Petrarca's Canzoniere (some of these are also in Dante's Comedy): "beltà", "bel desio", "in un punto", "occhi tuoi", "ogni impresa", "in un momento", "mercede", "in tal guisa", "l'ultima prova", "mio valor", "mia pietà", "a suo piacer", "bel nome", "un sol giorno", "misero stato", "occhi miei". Metastasio uses many poetical expressions which are found in Torquato Tasso's Gerusalemme liberata: "in ammenda del fallo", "le mie vendette", "fra noi non s'usa", "alcun de' suoi”, 
"il tuo fato", "serba nel cor", "il tuo periglio", "ciel sereno", "la tua destra", "i sensi miei", "lo stuol de", "le tue schiere", "morte al mio dolore", "a quel crudele", "onde a ragion". The language includes also several contemporary words. Though Metastasio follows the recommendations of the Accademia dell'Arcadia by choosing a poetical style which is more balanced and without excesses. Tasso's poetry intends to change the style of Ariosto's plots, coming back to the Aristotle's unities described in the Poetics [14] and in this way avoiding the mixing of different genres. The plot of Tasso tried to preserve the unity of the poem, without too many different stories and the excesses of the fabulous world in Ariosto. The aim of Tasso later became the same as of the Accademia dell'Arcadia and this probably is the reason of Tasso's influence in Metastasio's poetry.

At the end of XVII century, the language of opera librettos became "pure" following the new principles of Arcadia. However, an important innovation in the plot appeared: a new genre of opera was born in Naples, called opera buffa. Originally this opera style was not a mixture of different genres, as it eventually happened in the baroque period. The most important opera written in this new comic style was $L a$ serva Padrona (1733) with the music by Giovan Battista Pergolesi and the libretto by Gennaro Antonio Federico. The libretto is quite short, in comparison with others. Originally this opera was a comic intermezzo to be performed in the middle of another opera. In the plot, however, there are only comic characters, giving the official birth to the new genre, which derived from the theatrical comic style called commedia dell'arte. The libretto, even if quite short, shows some words which are also found in Petrarca, like "uopo", "queto" and "ruina". Some expressions in the libretto are found in Dante's Comedy, like "e tu '1 sai" (this was used also by Petrarca in Canzoniere), "in somma" and "suo loco". Even if the libretto makes use of an entire comic plot, which is far from the classic themes of vernacular poetry of XIV century, the language shows some similarities with that poetry. The language, however, is also closer to modern Italian. In the XVIII century the poets belonging to the Accademia dell'Arcadia were coming from all the Italian peninsula, still giving to the Florentine vernacular language the status of common language for literature in a context of different states with different dialects. The new comic style had the ambition to be exported outside Naples, using a common language for all the Italian peninsula. It was easier to produce comic effects using the dialect: in fact, one year before La serva padrona, Federico wrote another libretto for a comic opera, Lo frate 'nnamorato, using the Neapolitan dialect. Though it was the dialect a local language, it could not be understood outside the region of Naples. In this libretto we can see a minor influence of Florentine vernacular language: in a comparison of the libretto's texts with Petrarca's Canzoniere, we find some common expressions like: "mio cor", "si strugge", "mio foco", "mia speme", "non potea". The language of La serva padrona, on the contrary, gained a large popularity in the Italian states and, starting from the half of the century, also in France, where it raised the querelle des bouffons (War of the Buffoons) between defenders of French opera and supporters of the Italian opera. This querelle "in effect was a fight between the rising Rococo and the dying Baroque" [15]. The comic operas became very popular until the half of the XIX century and influenced also the music style. Several major composers wrote the music for comic librettos, in Italy notably Gioacchino Rossini.

Carlo Goldoni was among the major playwright and librettists of his time. He worked mainly in Venice and his comedies had a large impact on the audience in theaters. Representing the middle class with a new kind of realism and sometimes ridiculing the life of the aristocrats, Goldoni in his comedies often used the Venetian dialect. However, this feature of Goldoni's work was criticized by the most of writers of his century and also during the XIX century, arguing that his literature was too much devoted to business and the level of his style was not elevated. Only starting from the XX century Goldoni was considered by the critics a great author who reformed the theatrical literature. One of his achievements was to deny the typical improvisation in the commedia dell'arte, writing the plots in detail and giving to the actors a professional status. As a librettist, he wrote a significant number of librettos, avoiding the dialect used in comedies. Goldoni belonged officially to the Accademia dell'Arcadia but, in contrast to the Aristotle's Poetics, he started to mix the genres by writing tragicommedie and drammi giocosi. This mixture became very popular in the librettos along the XVIII century and thereafter.

Some Goldoni's works became very popular in all Europe [10], like for example Il filosofo di campagna (1754), a dramma giocoso to be performed with the music by Baldassarre Galuppi. Analyzing this libretto, it is still possible to find few reminiscences from Dante and Petrarca ("cor", "a guisa", "l'alma", "in questo loco", "la mia ragion", "il foco"), but it seems there is no trace of Tasso's poetry, like it was in Metastasio. Anyway, there are some language expressions which are found also in Ariosto's Orlando Furioso ("con patto che", "in un momento", "quanto è più", "Ma la ragione", "lo stato mio"). Ariosto, like Goldoni, was an author who sometimes mixed the genres. The style of Goldoni seems less "poetical" and appears closer to a sort of colloquial language, introducing words which are coming from fields other than poetry, like "giurisdizioni", "cambiali", "contratti", "fogli", "parapiglia" etc. This was also one of the reasons why he was criticized for a long time. This choice of words probably derived from new plots used by Goldoni. These plots were often far from mythological stories of serious opera. In the libretto there are some expressions which we also find in the prose of Boccaccio's Decameron ("esce di casa", "voi dovreste pensare", "per ventura", "se ne potrebbe", "il mio consiglio", "dinanzi agli occhi", "la vostra figliuola", "la sua fortuna", "il suo compagno", "la sua fede", "di tutto il mondo", "in un momento", "dopo il fatto"). The popularity of Goldoni increased so much that he worked also in Paris and wrote his last works in French.

Another great librettist of the XVIII century was Lorenzo Da Ponte. He followed the new theatrical tendencies and was 
the author of Don Giovanni (1787), a dramma giocoso with the music by Wolfgang Amadeus Mozart. He was influenced, among others, also by Goldoni: the characters belong to different social classes and the plot includes drama and comedy together. The libretto shows very few words or poetical expressions typical for Dante and Petrarca (like "meco" "alma", "il padre mio", "ché la gente", "da sé stesso"). However, there are many expressions which is possible to find in Boccaccio's Decameron ("agli occhi suoi", "E per questo", "un poco più", "mi parve che", "una gran festa", "in altra parte", "il mio tormento"), Ariosto's Orlando furioso ("non so che far", "le mie vendette", "di buon core", "il tuo compagno", "ben che lungamente") and Tasso's Gerusalemme liberata ("ferro ignudo", "il caro amante", "e con bell'arte", "a tanti segni", "spada al fianco", "da quel lato", "per la strada", "il buon vecchio", "se ti piace"). It is possible to find even more expressions like those used by Luigi Pulci in Morgante ("par che venga", "il cor mi sento", "qualche cosa ancor", "Sappi ch'io sono", "del mio dolor", "È questo il premio", "per tua difesa", "a poco a poco", "Io vo' veder se", "A me tocca", "per la strada", "si pasce di"). To amplify the comic style, Da Ponte also uses unpoetical words, or words used in poetry but modified in a pejorative meaning. Some examples are "scioccone", "inzuccherato", "bifolcaccio", "ceffo", "mascalzon", "scellerato", "briccona". This libretto shows the erudition of Da Ponte, who "quoted" many authors and, at the same time, could use a less elevated language in the comic parts. Together with the music of Mozart Don Giovanni became, with good reason, one of the most popular operas of all times.

It seems that after Goldoni the language of librettists was influenced by many authors, without selecting a particular genre of Italian literature. This was due to the mixture of genres: the style of writing changed and could rely also on the support of the prose, which basically could change from a serious to a comic style (like in Boccaccio's Decameron). The mixture of the genres, in this case, did not produce the complexity of baroque operas. Often the plots were simpler, and the mythological stories were used less frequently. This new tendency later developed in the romantic period, along with the changings of the music style.

\section{Discussion}

In the previous chapters the relationship between librettos and poetry was showed. However, there are also substantial differences between a libretto and a poetry's work. Both they use syllabic verses and rhymes, but in librettos we also can find very short verses, or a verse broken in two parts and singed by two characters. The reason of this being the presence of dialogues in the librettos and the length of opera which according to the Aristotle's unities, should last about one day. The dialogues are set in the present time and usually they are performed by two characters. In the middle of verses of Ariosto's poem Orlando Furioso there is also "the voice" of the poet introducing the characters or explaining the context of the plot. In this case there is no need to use short verses or to break the verse in two parts, while in operas it would be rather impossible to have a third character in a dialogue as a storyteller. For the same reason in the vernacular poetry it is always possible to have poetic forms like sonnets and canzoni, while in operas these forms would be difficult to adapt to the plot. So, due to the presence of dialogues, librettos in general have more freedom than poetry, but the presence of music itself also has a significant impact. According to Carl Dalhaus, the music is the predominant feature in opera [2]. However, an opera is made of words and music: the collaboration between librettists and composers in fact very often influenced the choice of the length of verses. For example, if the music had somewhere a fast tempo, the librettist could write short verses. The influence of music makes librettos conditioned by the choices of the composer and vice versa. The quality of a libretto, therefore, cannot be established without considering also the music.

The language of librettos, as it was explained, derives in most cases from the vernacular poetry. However, soon the librettos started to enlarge the dictionary to produce operas for all the kinds of audience, because sometimes the plots were not compatible with the models of poetry of the XIV or XV century. The spread of theaters in all the Italian peninsula in XVII century testifies to the huge success of opera. Thousands of operas were written in the Italian states and, later, in other European states. It is not surprising that, being a commercial success, operas could sometimes also be written using dialects or including words outside the poetry's borders. While the poetry had a more selective audience, many social classes could afford the price of tickets to watch operas. This is probably the reason for the different approach of librettists while writing librettos: opera became something similar to a mass phenomenon and the language, the plots and the music took in consideration the taste of the audience. However, the language of most of librettos always had some connections with the vernacular poetry of XIV century, even if there was a compromise with the needs of audience. It is always possible to find some reference to Dante or Petrarca in the librettos. It seems that librettists wanted to give their works a certain poetry's status, quoting the fathers of vernacular poetry, or eventually they wanted to keep intact some basic rules of early opera librettos.

Petrarchism is a cultural movement which lasts for centuries and can be found in the poetry of the Italian states and abroad [7]. Librettos were also often influenced by Petrarca, but they were also subjected to the influence of audience, plots and music.

In any case the librettos, in the author's opinion, can be considered a genre of poetry, mainly because there are some rules in their writing and also because the language, in most of librettos, is the Florentine vernacular, which was regarded as the language of literature. Furthermore, the librettos followed the same tendencies of literature along centuries, especially in the use of language. There was sometimes the compromise according to the market requests, giving the librettos a commercial appeal, but in general the connection with literature is always present. This makes librettos a part of literature. 


\section{Conclusions}

The analysis of some libretto's texts from a particular time period shows their close connection with poetry, starting already from the Florentine vernacular poetry of XIV century. This makes librettos a part of literature. If we search for a definition of the term literature in a dictionary, we find that it is "a set of works with the aim of aesthetic purposes" [16]. This seems to be the case of the opera librettos. Most of librettists were poets and their works reflect the tendencies of literature at their time, even if the librettos are subjected to possible compromises with music and market needs. An opera is a mixture of text and music, but also the plot should be taken in consideration for an aesthetic opinion. However, even if only the single text of librettos is taken in consideration, it is possible to evaluate the quality of writing according to the poetical style or to the literary taste in a particular time.

\section{References}

[1] G. Gronda, P. Fabbri. Libretti d'opera italiani dal Seicento al Novecento. Milano: Mondadori, 2014.

[2] C. Dalhaus. Drammaturgia dell'opera italiana. Torino: EDT, 1988.

[3] I. Bonomi, E. Buroni. Il magnifico parassita. Librettisti, libretti e lingua poetica nella storia dell'opera italiana. Milano: Franco Angeli, 2010.

[4] L. Pavan. "An Automatic Translator from the Florentine Vernacular Language to Modern Italian Language". International Journal of Literature and Arts. Vol. 7, No. 5, 2019, pp. 126-131. doi: 10.11648/j.ijla.20190705.16.
[5] G. Staffieri. L'opera italiana. Dalle origini alle riforme del secolo dei Lumi (1590-1790). Roma: Carocci, 2014.

[6] P. Fabbri. Metro e canto nell'opera italiana. Torino: EDT, 1988.

[7] PMP - Il Petrarchismo. Un modello di poesia per l'Europa. vol. 1. Roma: Bulzoni, 2006.

[8] I. Bonomi, E. Buroni. La lingua dell'opera lirica. Bologna: il Mulino, 2017.

[9] F. Dorsi. Storia dell'opera italiana. Vol. 1. Il Seicento, il Settecento. Milano: Casa Musicale Eco, 2016.

[10] C. Abbate, R. Parker. A History of Opera. The Last Four Hundred Years. London: Penguin Books, 2012.

[11] P. Fabbri. Il secolo cantante. Per una storia del libretto d'opera in Italia nel Seicento. Roma: Bulzoni, 2003.

[12] I. Czigány, "L’Orlando Furioso e le peculiarità dell'opera lirica veneziana del Seicento e del Settecento". Verbum Analecta Neolatina. Vol. XIII/2, 2012, pp. 477-482, doi: 10.1556/Verb.13.2012.2.14.

[13] VDC - Vocabolario degli Accademici della Crusca, Venezia: Giovanni Alberti, 1612.

[14] G. Paduano (ed.). Aristotele. Poetica. Bari: Laterza, 1998.

[15] W. Apel. Harvard Dictionary of Music. Cambridge, Massachussets: The Belknap Press of Harvard University Press, 1972.

[16] VT - $\quad$ Treccani. Vocabolario. URL http://www.treccani.it/vocabolario/letteratura/(Accessed:13/11 /2019). 